\title{
Sistem Informasi Pengolahan Data Nilai Siswa Berbasis Website Pada MTs Mishbahul Falah Batangan
}

\author{
Diah Ayu Ambarsari ${ }^{1}$ \\ 1, Program Studi Sistem Informasi, Sekolah Tinggi Manajemen Informatika dan Komputer Nusa Mandiri \\ J1. Jatiwaringin Raya No. 2, Jakarta Timur, Daerah Khusus Ibukota Jakarta, Indonesia \\ e-mail: ${ }^{1}$ diah.das@ nusamandiri.ac.id
}

Artikel Info : Diterima : 12-01-2021 $\mid$ Direvisi : 14-01-2021 | Disetujui : 15-01-2021

\begin{abstract}
Abstrak - Madrasah Tsanawiyah Mishbahul Falah merupakan salah satu lembaga pendidikan, namun dalam proses penghitungan nilai masih tergolong manual karena dalam teknisnya guru mata pelajaran memberikan daftar nilai siswa kepada wali kelas, kemudian wali kelas menyalin nilai siswa ke dalam buku rapor berdasarkan data nilai yang diterimanya. Pengolahan nilai yang masih manual membuat pekerjaan lebih lama diselaikan, tingkat kesalahan dalam pengolahanpun lebih besar. Tujuan Penelitian ini membangun aplikasi yang dapat memberi kemudahan dalam pengolahan nilai dengan menggunakan metode waterfall. Tahap awal dalam penelitian ini dengan mengumpulkan data untuk analisis, kebutuhan analisis sistem yang akan digunakan meliputi analisis perangkat keras, perangkat lunak, pengguna, teknologi, perancangan sistem, basis data, antar muka, implementasi sistem, dan pengujian sistem. Hasil penelitian ini adalah Aplikasi Pengolahan Data Nilai Siswa Berbasis website. Aplikasi yang dibuat dapat menyimpan data sekolah antara lain, guru, kelas, mata pelajaran, siswa, tahun ajaran, serta melakukan proses penilaian. Aplikasi ini diharapkan mampu mengatasi permasalahan guru atau wali kelas dalam proses pengolahan data nilai siswa.
\end{abstract}

Kata Kunci : Aplikasi Pengolahan Nilai Siswa, Sistem, website

\begin{abstract}
Madrasah Tsanawiyah Mishbahul Falah is an educational institution, but in the process of calculating grades it is still classified as manual because technically the subject teacher provides a list of student scores to the principal, then the class teacher copies the student's scores into a report card based on the value data. Assessing that processing is still manual makes the longer work done, the greater the error rate in processing. The purpose of this study is to build applications that can facilitate value processing using the waterfall method. The initial stage in this research is to collect data for analysis, system analysis which will be used includes analysis of hardware, software, users, technology, system design, database, interface, system implementation, and system testing. The results of this study are Web-Based Student Value Data Processing Applications. Applications that are made can store school data, including teachers, classes, subjects, students, academic years, and carry out the assessment process. This application is expected to be able to solve the problems of the teacher or principal in the process of processing student value data.
\end{abstract}

Keywords : Student Value procesing Application, System, website

\section{PENDAHULUAN}

Ilmu pengetahuan dan teknologi selalu mengalami kemajuan sesuai dengan perkembangan zaman. Kemajuan teknologi ditandai dengan semakin canggihnya teknologi. Perkembangan zaman juga berdampak pada pendidikan bidang sarana dan prasarana khusunya pada era 4.0. Semua informasi pendidikan bisa didapat melalui internet dan dapat di akses melalui berbagai perangkat elektronik. Salah satu pemanfaatan kecanggihan teknologi dalam dunia pendidikan adalah pengolahan nilai di sekolah (Pangastuti \& Priantinah, 2019).

Mutu pendidikan bisa dikatakan berkualitas ketika prospek kedepanya lebih baik dari pada keadaan sebelumnya , untuk merealisasikan hal tersebut harus mengevaluasi secara matang agar terciptanya pendidikan yang berkualitas (Napiah, Raharjo, Putra, Heristian, \& Leksono, 2020).

This work is licensed under a Creative Commons Attribution-ShareAlike 4.0 International License. 
MTs. Mishbahul Falah Klayusiwalan Kecamatan Batangan Kabupaten Pati. MTs. Misbhbahul Falah ini berdiri pada tanggal 22 Juni 1993 berada di bawah naungan Yayasan Perguruan Mishbahul Falah Klayusiwalan. Alasan didirikannya MTs. Mishbahul Falah Klayusiwalan adalah banyak orang tua yang sudah sadar pada pendidikan baik umum maupun pendidikan agama. Banyak orang tua yang merasa perlu menyekolahkan anaknya pada lembaga pendidikan yang memiliki nilai tambah dalam bidang agama.

Sistem pengolahan data nilai siswa merupakan salah satu implementasi sistem back office (sistem adminitrasi) yang akan digunakan untuk mempermudah guru dalam mengelola data nilai siswa yang ditangani oleh masing-masing wali kelas. Proses penilaian yang berjalan pada MTs. Mishbahul Falah dalam mencatat nilainilai ulangan harian, tugas, ujian semester dan ujian akhir semester siswa masih menggunakan lembaran-lembaran kertas yang jumlahnya cukup banyak dan harus direkap kembali dalam buku induk siswa.

Banyak sekolah maupun perguruan tinggi yang bertransformasi dari pengolahan nilai secara manual ke pengolahan nilai secara digital, salah satunya STIMIK IBBI. Penelitian tersebut bertujuan dapat mengolah data secara benar dalam data yang begitu kompleks dan meminimalisir kesalahan, penelitian ini menggunakan Object Oriented Analysis, pengembangan perangkat lunak menggunakan visual studio Code dan database yang di gunakan MySQL pengujian di lakukan secara blackbox testing (Selamat, 2017)

Pada penilitian yang berjudul Website Rapor Online Pada Sekolah Dasar Islam Terpadu Istiqomah Lembang, membangun Sistem Raport Onlien .Perhitungan nilai yang di lakukan secara manual membuat orang tua atau wali murid susah mendapatkan informasi mengenai nilai putra-putrinya dan dalam perhitunganya pun sering mengalami kesalahan. Perancangan yang di gunakan dalam studi kasus ini menggunakan waterfall(Mayya Nurbayanti Shobary, 2017)

Pada penelitian yang berjudul Prototype Sistem Informasi Pengolahan Nilai Dengan Metode Prototype memiliki anatmuka 4 user yaitu siswa atau wali murid, Admin, wali kelas . Dalam penelitian menggunakan metode wawancara , observasi , studi pustaka dan dalam pengembangan menggunakan metode prototype, penulis juga mengusulkan menggunakan Entitty Relatiionship Diagram (ERD) ,Logical Record Structure Structure Isebagai rancangan databaseidan didukung diagram UML (Saefudin \& Andriani, 2020)

Adapun masalah yang sering dialami oleh pihak sekolah dalam mengelola data nilai siswa yaitu guru atau wali kelas harus menulis dua kali data nilai siswa pada buku induk siswa dan data nilai yang diberikan pada siswa, sehingga hal ini kurang efesien baik dalam penggunakan waktu dan tenaga, berikutnya adalah mengelola data sekolah yaitu data diri siswa, data guru, data mata pelajaran dan data nilai siswa yang harus direkap dalam buku induk sekolah, ini memperlukan tempat yang banyak dan merepotkan apabila terjadi pergantian data, terhapus atau hilangnya data baik disengaja maupun tidak.

Pihak sekolah menyadari bahwa pekerjaan pengelolaan data nilai siswa adalah tugas yang merepotkan, sehingga pihak sekolah menginginkan adanya suatu sistem pengelolaan data nilai siswa yang dapat membantu atau mempermudah guru dan wali kelas, serta pengelolaan data induk siswa yang lebih efesien dalam segi tenaga dan waktu.

Berdasarkan uraian permasalahan di atas akan dibangun aplikasi yang dapat membantu guru dan pihak sekolah untuk mengelola nilai siswa dan mengelola ledgersiswa yang terintegrasi komputer. Teknologi pendukung penelitian berupa PHP dan basis data MySQL. Aplikasi yang di bangun user requitment adalah sebagai berikut adanya fasilitas layanan cetak rapor nilai suswa dan data induk siswa dapat diolah secara efektif dan efesien sehingga informasi dapat tersampaikan dengan baik kepada siswa dan dampak pada meningkatnya kinerja guru.

\section{METODE PENELITIAN}

Pada penelitian Pembuatan Sistem Informasi Pengolahan data nilai siswa berbasis website Pada MTs Mishbahul Falah Batangan metode pengembangan perangkat lunak menggunakan waterfall atau sering di sebut metode air terjun . Metode ini menyelesaikan tahap demi tahap. Metode waterfall terdiri dari analis, desain, kode , pengujia dan pemeliharaan (D. Wijaya \& W. Astuti, 2019). Namun pada penelitaian ini hanya pada sampai tahap pengujian .

\section{A. Terdapat 5 tahapan penelitian :}

1. Analisis Kebutuhan Perangkat Lunak

Tahap pertama kali yang harus dilakukan adalah menganalisa kebutuhan perangkat lunak agar kita dapat mengetahui spesifikasi, informasi, model dari sistem yang akan di butuhkan

2. Desain Perangkat Lunak

Tahapan ini bertujuan untuk membuat desain dari hasil analisis yang dilakukan pada tahap pertama. Model, spesifikasi, dan informasi yang diubah menjadi sebuah sistem yang nantinya akan dikodekan. Proses ini mengimplementasikan konfigurasi dari aplikasi. 
3. Coding

Pada desain yang telah di buat akan di lakuakan pengokeadn dengan bahasa pemrograman yang akan di baca oleh komputer yang akan menghasilakan tampilan/ interface dapat di baca dan digunakan oleh user.

4. Pengujian

Setelah sistem terbangun dan melawati tahap desain , pengkodeaan, barulah pengujian sistem. Pada tahap ini bertujuan menguji sistem yang baru di bangun. Pengujian dapat di lakukan dengan black box testing dan white box testing

5. Pemeliharaan

Pemeliharaan biasanya merupakan fase siklus yang paling lama (walaupun tidak seharusnya) sistem diinstall dan di pakai

\section{PEMBAHASAN}

\section{A. Diagram Konteks}

Proses transformasi data input menjadi output di gamabrakan dalam diagram konteks, pada diagram ini menggambarkan hubungan entitas luarmya dengan siistem (Andrianto \& Wijoyo, 2020). Proses berjalan sistem dari aplikasi alur data keterlibatan pelaku sistem informasi dapat di gambarkan dalam bentulk diagram Konteks



Gambar 1: Diagaram Konteks

Keterangan diagram konteks diatas :

1. Admin : yang berinteraksi langsung dengan sistem dalam pengolahan data guru, wali kelas, mata pelajaran, tahun ajaran, ruang kelas, siswa, dan data admin yang meliputi input, edit, dan hapus.

2. Siswa : tidak secara langsung berinteraksi dengan sistem. Siswa hanya menerima output dari sistem berupa laporan hasil nilai belajar.

3. Guru : berinteraksi langsung dengan sistem dalam pengolahan data nilai siswa yang meliputi input nilai siswa.

4. Wali kelas : berinteraksi langsung dengan sistem. Wali kelas juga bisa input nilai siswa, nilai pengembangan diri, dan input data absen serta cetak rapor.

A. Use case

Use case di gunakan untuk menggambarkan satu atau banyak skenario untuk menerangkan berjalanya sistem berinteraksi antara actor dengan use case untuk mencapai tujuan tertentu (Handayani, 2018) Use case tidak menerangkan kinerja sistem secara implementasinya, namun use case menjelaskan bagaimana langkah-langkah user/pengguna dalam menggunakan perangkat

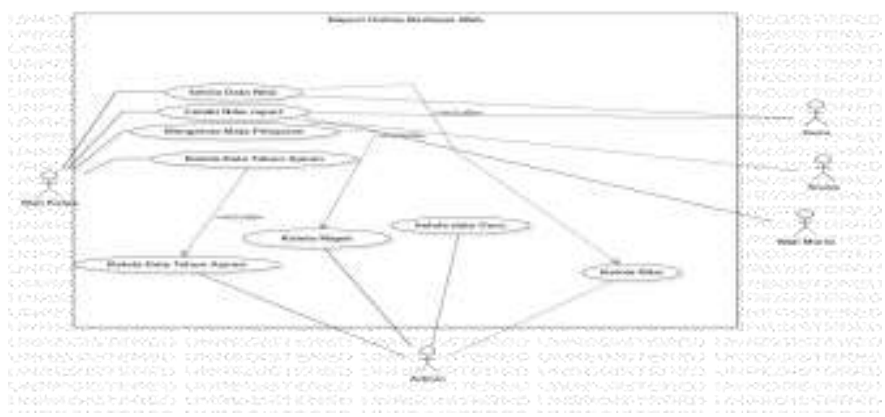

lunak(Mahdiana, 2016)

Gambar 2: Use case diagram pengolahan nilai rapor 
Pada penelitian ini terdapar 5 aktor yaitu siswa, wali murid, admin, wali kelas dan guru . Use case diatas menggambarkan bahwa semua aktor dapat login pada sistem namun memiliki hak akses yang berbeda. Aktor admin dapat mengakses atau mengelola fitur yang ada pada sistem . Siswa dan wali murid hanya dapat melihat dan mencetak nilai rapor dan Guru dapat mengelola nilai sedangkan wali murid selai mengelola nilai juga bisa mengelola data tahun ajaran dan mata pelajaran.

\section{B. Relasi Antar Tabel}

LRS (Logical Record Struktured) merupakan model sistem digambarkan pada sebuah diagram ER yang mengikuti pemodelan yang sudah di tentukan dengan konveksi ke LR(Larasati \& Masripah, 2017). Table- table dengan entitas saling berhubungan merecord ke dalam sistem untuk menentukan jumlah table foreignKey, Kardinalitas (Mita, Muhamad, \& Surtika, 2018)

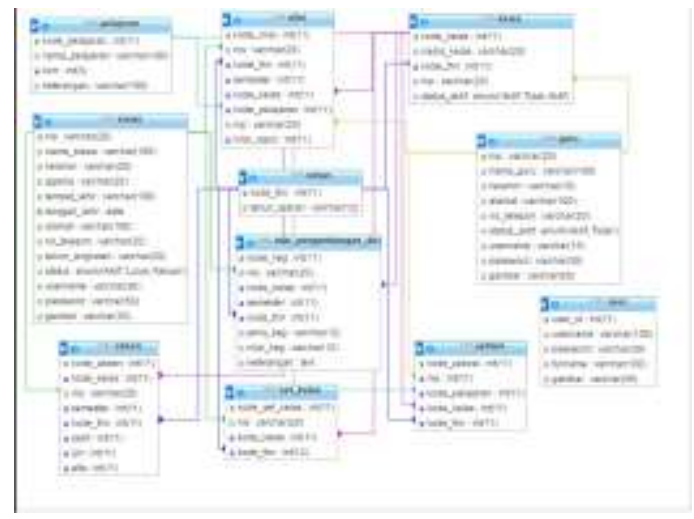

Gambar 3: Logical Record Struktured Pengolahan Nilai Rapor

\section{Perancangan Struktur Menu Utama}

Setelah user memilih pada form menu login maka sistem akan mengecek pada database apakah sesuai dengan data pada database atau tidak, jika tidak maka akan kembali ke menu index, jika ya maka sistem akan berlanjut ke menu selanjutnya sesuai dengan hak akses yang dipilih yaitu sebagai admin, guru, wali kelas, dan siswa



Gambar 4 : Perancangan Struktur Menu

Aplikasi pengolahan data nilai siswa berbasis website ini memiliki beberapa menu user yaitu, menu admin, menu guru, menu wali kelas dan menu siswa. Setiap menu user yang ada memiliki fungsi yang berbeda yaitu:

1. Menu admin

a. Halaman depan : merupakan halaman awal setelah login, berisi menu.

b. Tahun ajaran : merupakan halaman yang berisi untuk mengelola data tahun ajaran.

c. Data induk : merupakan halaman yang berisi untuk mengelola data siswa, data guru, data wali kelas, dan data mata pelajaran. 
d. Penjadwalan : merupakan halaman yang digunakan untuk mengelola ruang kelas siswa dan data pengajar.

e. Admin : merupakan halaman yang berisi untuk mengelola data admin.

f. Laporan : merupakan halaman digunakan untuk mengelola laporan

g. siswa, laporan ruang kelas, laporan pengajar, laporan guru, laporan nilai siswa.

2. Menu guru

a. Halaman utama : merupakan halaman awal setelah login, yang berisi data mata pelajaran yang diajar dan berisi data nilai.

b. Data nilai : merupakan halaman yang berisi data nilai siswa dan guru menginputkan nilai siswa.

3. Menu wali kelas

a. Halaman utama: merupakan halaman awal setelah login, yang berisi data mata pelajaran yang di ajar dan data kelas yang di wakili

b. Menu data absen dan kegiatan : merupakan halaman yang berisi data absensi siswa dan data kegiatan siswa.

4. Menu siswa

a. Halaman utama : merupakan halaman awal setelah login, yang berisi data siswa.

b. Menu tahun ajaran : merupakan halaman dimana berisi data nilai siswa.

D. Interface

1. Tampilan Halaman Login

Hasil halaman awal Sistem Informasi Pengolahan Data Nilai Siswa Pada Madrasah Tsanawiyah Mishbahul Falah batangan adalah sebagai halaman login. Seperti yang tertera pada Gambar 5



Gambar 5 : Halaman Tamoilan Login

Pada halaman login ini terdapat beberapa form login, diantaranya ada form login admin, login sebagai siswa, login sebagai guru, dan login sebagai wali kelas.

\section{Halaman Utama Admin}

Setelah berhasil login sebagai admin maka akan muncul halaman sebagai berikut. Seperti yang tertera pada Gambar 6



Gambar 6 : Halaman Utama Admin

Seperti yang tertera pada gambar, halaman ini terdapat beberapa menu dan laporan. Untuk menu ada dibagian samping kiri yang berisi ada menu tahun ajaran, data induk, penjadwalan, admin dan laporan. 


\section{Halaman Utama Siswa}

Setelah login sebagai siswa maka akan muncul halaman utama pada index guru seperti berikut. Seperti yang tertera pada Gambar 7



Gambar 7: Halaman Utama Siswa

\section{Halaman Utama Guru}

Setelah login sebagai guru maka akan muncul halaman utama pada index guru seperti berikut. Seperti yang tertera pada Gambar 8

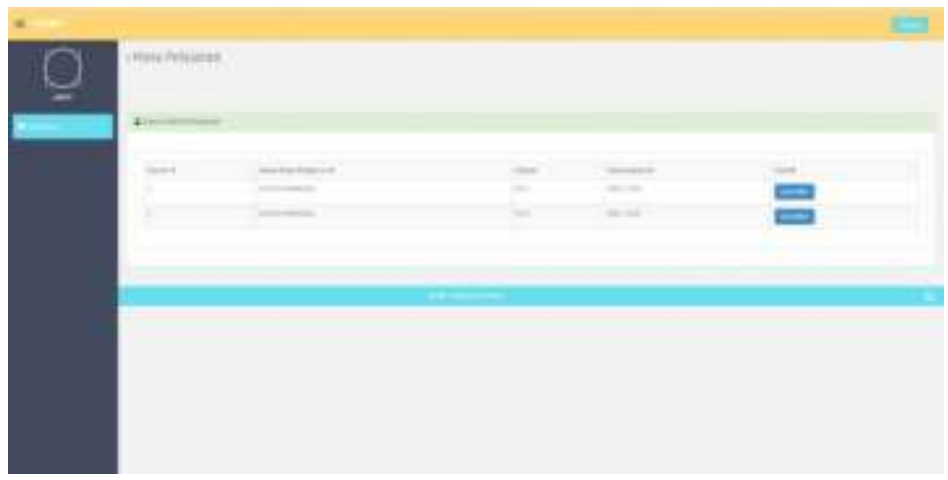

Gambar 8: Halaman Utama Guru

Seperti yang tertera pada gambar, halaman ini berisi tentang daftar mata pelajaran yang diampu,kelas, dan siswa yang diajarkan oleh guru sesuai dengan user login yang digunakan

\section{Halaman Input Nilai}



Gambar 9: Halaman Utama Guru

Pada Gambar 9 Halaman input nilai menampilkan nama guru, pelajaran, kelas tahun ajaran yang diambil sesuai dengan user login yang di gunakan. Sedangkan nama siswa diambil dari siswa yang kelas tersebut diampu dan memasukkan jumlah nilai pelajaran. 


\section{Halaman Utama Wali kelas}

Setelah login sebagai wali kelas maka akan muncul halaman utama pada index wali kelas seperti yang tertera pada Gambar 10.

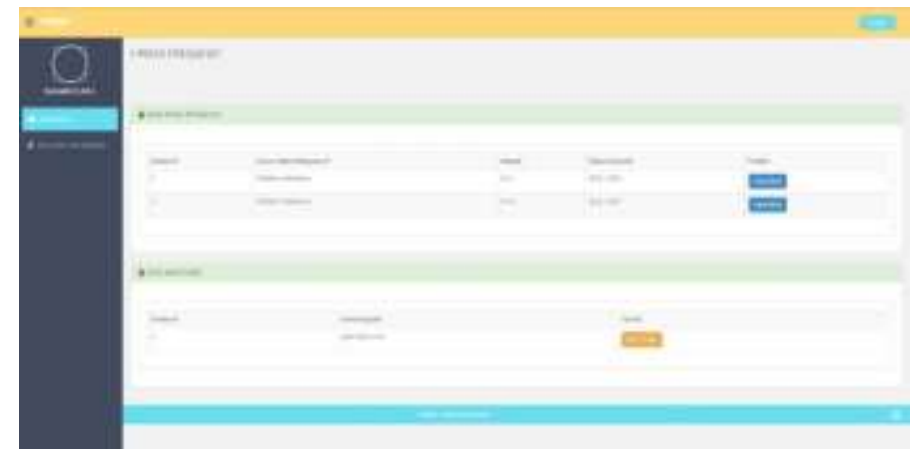

Gambar 10: Halaman Utama Guru

Pada gambar diatas terdapat menu dashboard, menu data absen dan kegiatan. Dalam main area terdapat laporan mata pelajaran yang diampu serta kelas yang diwakili.

\section{Halaman Data Absen}



Pada Gambar 11 Diatas dalam area terdapat data absen siswa, jadi nilai absen pun akan terakumulasi secara otomatis.

\section{Halaman Input Absen}

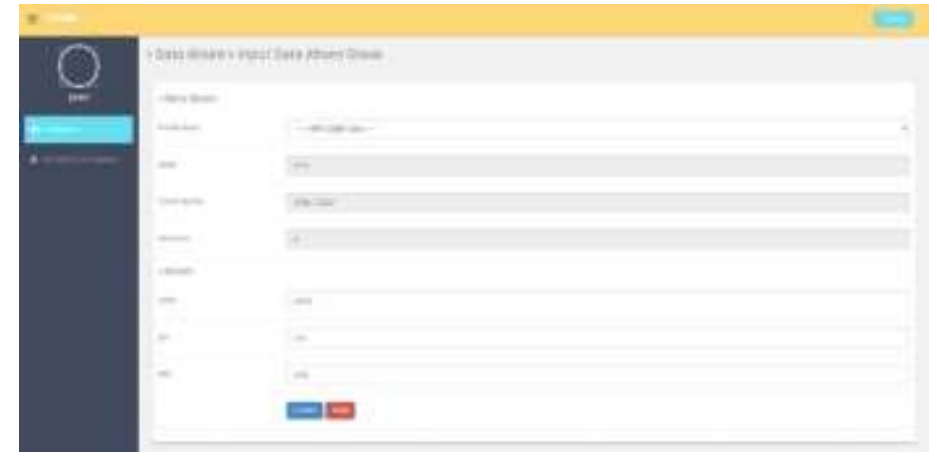

Gambar 12: Halaman Utama Guru

Pada 12. Halaman input absen menampilkan nama siswa, kelas, tahun ajaran, semester yang diambil sesuai dengan user login yang di gunakan. Sedangkan nama siswa diambil dari siswa yang kelas tersebut diampu dan memasukkan jumlah nilai pelajaran. 


\section{Halaman Cetak Raport Siswa}

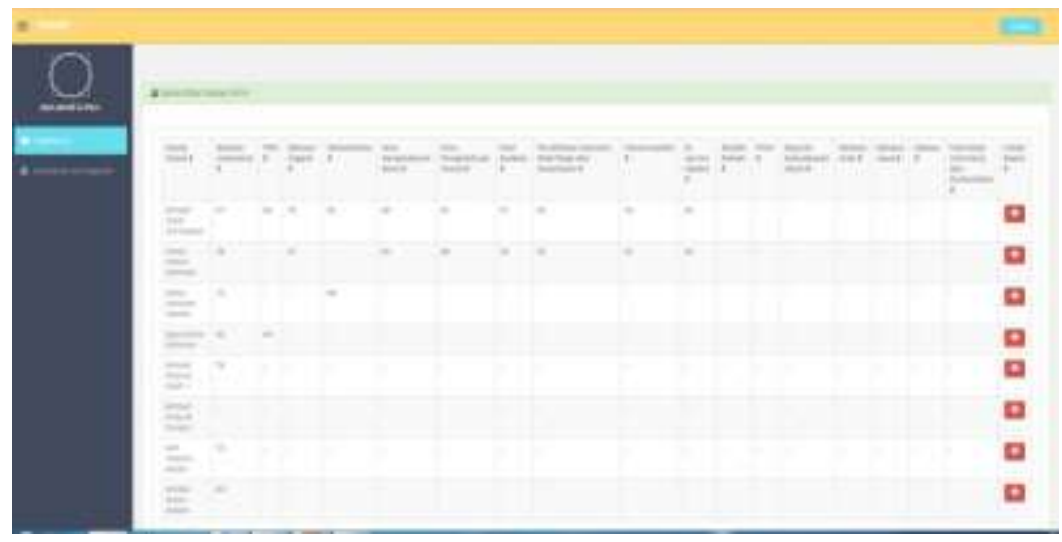

Gambar 13: Halam Cetak Rapot

Halaman untuk menampilkan laporan nilai siswa yang kelasnya diwakili guru tersebut. Siswa/wali murid juga dapat mencetak hasil nilai .

\section{Halaman print Out Rapor Siswa}

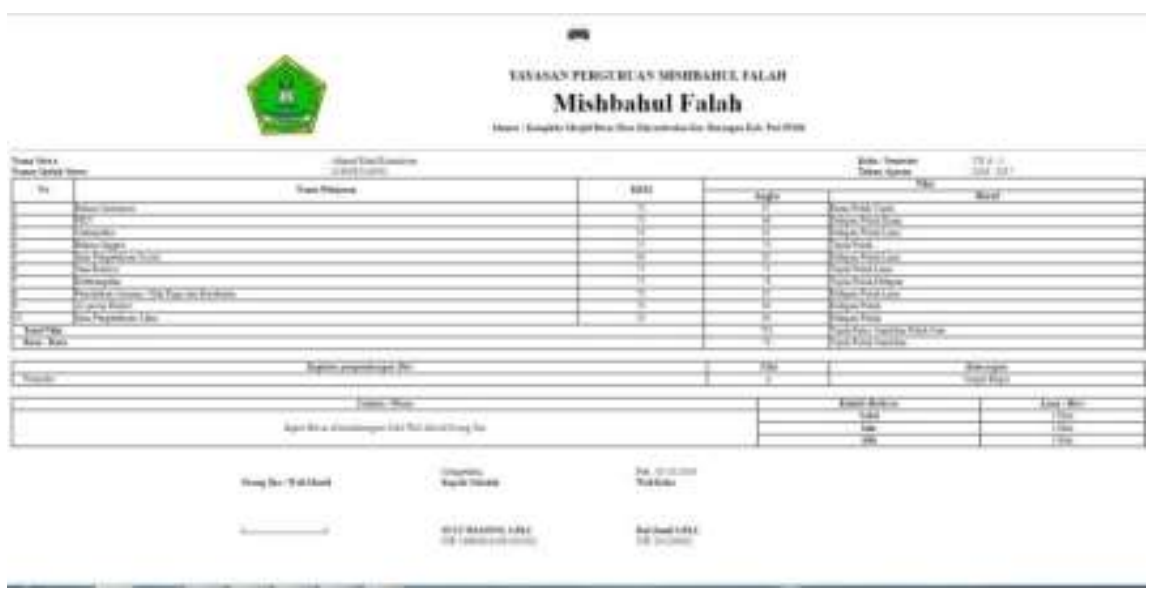

Gambar 14 : Print Out Rapor Siswa

Pada Gambar 14. Merupakan print out rapor siswa, halaman ini menampilkan semua nilai hasil belajar siswa serta absensi siswa.

Pada Penelitian ini dilakukan pengujian secara acak untuk memastikan apakah sistem yang dihasilkan sudah sesuai dengan rancangan yang dibuat. Pengujian yang dilakukan berfokus pada persyaratan fungsional perangkat lunak. Pengujian ini bertujuan untuk menunjukkan cara operasi fungsi perangkat lunak dan untuk mengetahui apakah data masukan dan keluaran sudah sesuai dengan diharapkan. Dalam hal ini adalah data siswa, data guru, nilai siswa dan rapor siswa.

Admin memasukkan data siswa, guru, kelas dan daftar mata pelajaran, serta mengatur jadwal pengajaran untuk para siswa dan untuk admin dapat mengelola semua data siswa, guru, kelas, mata pelajaran dan penjadwalan, serta cetak rapor.

Jika guru sudah memasukkan nilai siswa sesuai dengan mata pelajaran yang diajarkan. Wali kelas memasukkan data absen dan nilai pengembangan diri setelah itu wali kelas dapat melakukan cetak rapor ketika para guru pengajar sudah memasukkan nilai masing-masing siswa pada setiap mata pelajaran yang diajarkan oleh guru. Siswa bisa melihat data laporan nilai. 


\section{KESIMPULAN}

Berdasarkan hasil penelitian tentang Sistem Informasi Pengolahan Data Nilai Siswa Berbasis Website Pada MTs Mishbahul Falah, dengan metode waterfall membuat pekerjaan lebih efektif dan lebih akurat dalam pengolahanya. Pada Sistem Informasi Pengolahan Data Nila sudah dapat menampiilkan laporan dengan melakukan login terlebih dahulu. Sistem ini juga sangat membantu dalam pengarsipan data dan dan pencetakan nilai secara otomatis.

\section{REFERENSI}

Andrianto, S., \& Wijoyo, H. (2020). Rancang Bangun Sistem Informasi Siswa Berbasis website di Sekolah Minggu Buddha Vihara Dharmaloka Pekanbaru. TIN : Terapan Informatika Nusantara, 1(2), 83-90.

D. Wijaya, Y., \& W. Astuti, M. (2019). Sistem Informasi Penjualan Tiket Wisata Berbasis Web Menggunakan Metode Waterfall. Prosiding Seminar Nasional Teknologi Informasi Dan Komunikasi (SENATIK), 2(1), 273-276.

Handayani, S. (2018). Perancangan Sistem Informasi Penjualan Berbasis E-Commerce Studi Kasus Toko Kun Jakarta. ILKOM Jurnal Ilmiah, 10(2), 182-189. https://doi.org/10.33096/ilkom.v10i2.310.182-189

Larasati, H., \& Masripah, S. (2017). Analisa Dan Perancangan Sistem Informasi Pembelian Grc Dengan Metode Waterfall. Jurnal Pilar Nusa Mandiri, 13(2), 193-198.

Mahdiana, D. (2016). Pengadaan Barang Dengan Metodologi Berorientasi Obyek: Studi Kasus Pt . Liga Indonesia. Jurnal TELEMATIKA, 3(2), 36-43.

Mayya Nurbayanti Shobary, M. I. F. (2017). Website Rapor Online Pada Sekolah Dasar.

Mita, agnitia L., Muhamad, T., \& Surtika, A. (2018). Sistem Informasi Pengolahan Data Administrasi Kependudukan Pada Kantor Desa Pucung Karawang. Jurnal Interkom Vol. 13 No. 3, 13(3), 14-21.

Napiah, M., Raharjo, M., Putra, J. L., Heristian, S., \& Leksono, I. N. (2020). Rancang Sistem Penyajian Bank Soal Untuk Jenjang Sekolah Menengah Atas Berbasis Web. 2(2).

Pangastuti, A. D., \& Priantinah, D. (2019). Penerapan Sistem Informasi Raport Online. Ekuitas: Jurnal Pendidikan Ekonomi, 7(1), 1. https://doi.org/10.23887/ekuitas.v7i1.16488

Saefudin, Y. A., \& Andriani, A. (2020). Prototipe Sistem Informasi Pengolahan Nilai Dengan Metode Prototype. 12(1).

Selamat, T. (2017). Sistem Informasi Pengolahan Data Nilai Siswa Berbasis Web Pada. 8(3), 11160429. 